\title{
A Tentative Research on the College English Reading Teaching Mode Based on the Theory of the Flipped Classroom
}

\author{
Sufen $L U^{1, a}$ \\ ${ }^{1}$ Department of Foreign Languages \\ Changsha Medical University, Hunan, Changsha 410219,China \\ a lusufenhn@126.com
}

Keywords: Flipped classroom; College English Reading; Application

\begin{abstract}
Flipped classroom, which focuses on improving the students' autonomous learning, is dissimilar to the traditional teaching mode. With the fast development and popularization of modern technology, people's life and study have undergone great changes and the traditional college English teaching mode can no longer meet the needs of the teachers and students. The College English teaching reform is imminent. In this paper we are probing into the possibility of new ways of English reading teaching since reading skill is of enormous importance in the English learning. And also through the analysis of the advantages of English reading teaching mode based on the theory of the flipped classroom in several aspects, we are attempting to provide the reference for the reform of college English teaching and improve the teaching and learning efficiency in practice.
\end{abstract}

\section{Introduction}

The emergence of flipped classroom provides a refreshing view for the teaching of college English teaching. At present, Chinese scholars' research on the ability acquisition of English reading still falls on the premise of traditional classroom teaching mode, where the students learn English reading materials under the guidance of the teacher. However, more and more teachers have found that traditional teaching method is no longer suitable for the E-generations. With the introduction of new teaching patterns based on the Internet such as MOOC courses, micro lectures and flipped classes, an unprecedented curriculum teaching reform has gradually formed in many fields.Applying flipped classroom theory to the English reading courses makes it possible for students to enjoy a freer reading style, a richer reading content, and a more outstanding reading effect.

\section{The Feasibility of Applying the Flipped Classroom to English Reading Course}

Flipped classroom teaching mode is highly effective and plays a very crucial role in college English teaching reform.Flipped Class Model mainly refers to the flipping of the learning time and key learning points inside and outside the classroom, namely, students complete knowledge learning outside the classroom, and it emphasizes the interaction between teachers and students or even between students and students in the classroom ${ }^{[1]}$. A successful flipped classroom can never be created without the popularity of the Internet and technical support.

Through short, clearly-targeted supplementary video clips, a flipped class completes message transmission before class. On the one hand, teachers utilize their own camera or smart phones and adequate video editing software or make use of multimedia teaching resources directly collected from the Internet to create a variety of teaching videos. On the other hand, the students just need computes hooked up to the Internet, or even a smart phone accessed to a wireless wifi to realize autonomous learning anytime and anywhere. Flexible and comprehensive network platform can satisfy the demand for personalized learning and learners can easily acquire guidance and help in the process of independent learning ${ }^{[2]}$. 


\section{The Advantages of Flipped English Reading Course}

\section{A. Providing the Latest English Reading Material}

The 21st century is the age of information explosion and the international exchange is becoming more and more frequent and so the mastery of trendy material is supposed to be a crucial part in English reading teaching.A flipped English reading class facilitates the practice of classroom teaching. Extracurricular "information transferring" actually wins the time for "absorption and internalization" in class. In addition to teaching reading skill, teachers need to elaborate classroom activities suitable for reading themes according to students' levels and interests ${ }^{[3]}$. For example, an article entitled Alibaba's Future: Dominant Market Player or Dynamic Growth Engine? on CRIEnglish.com aroused great interests among the customers and students because it's published right after the boom of sales promotion on $11^{\text {th }}$ November. In the process of learning this article, the teacher can organize students in groups to debate on online shopping issues, and let students obtain the greatest benefit in the learning process of "absorption and internalization".

\section{B. Optimizing the Class Time}

In the flipped classroom teaching mode, the students have to prepare in advance for a new teaching content and teachers in the classroom just help solve troubles, which can save a lot of class time and provide students with more opportunities for interaction, cultivating their analysis and problem solving skills. Take the article entitled The Happy Man as an example. The teacher can make out the emphases and difficulties of the text and make relevant teaching videos which focus on the grammar, translation and vocabulary knowledge. At the same time, in the class, the teacher doesn't have to spend a lot of time on word for word translation or interpretation of the grammar points. More class time can be used to solve the difficult problems and improve the teaching quality.

\section{C.Helping Students to Improve Reading Speed and Enlarge Vocabulary}

In a flipped English reading class, teachers can select different articles with the same theme and at moderate lengths and turn them into courseware or e-books. Software makes it possible to monitor students' reading speed and help them train their reading skills on their own. In the meanwhile, each section of the video can be paused and replayed,which facilitates students' online study;practice of words or difficult sentences after each article can help students understand their learning effect, adjust the learning state and ultimately clear the language barrier for classroom activities $^{[4]}$.

\section{Realizing the Personalized Learning}

Each person has different learning ability ,hobbies and interests.Flipped class provides students with free relaxed learning environment and personalized learning resources, so that the students can choose suitable learning content and resources according to their personality and special needs to make progress in their own way.In applying the flipped class in English reading teaching, teachers will take into account the differences of the students, do the layering teaching help each student learn at their own speed. Fast learning students can master more difficult course content and slow students can study repeatedly to improve the comprehension.

\section{E.Cultivating the Students' Critical Reading Skills}

In recent years, teachers of English education have gradually reached a consensus to strengthen students thinking ability, while traditional model of reading lays too much emphasis on teaching language skills. Faced with the world's objective reality---"diversification in value, expressions and experiences", people read articles on newspapers and magazines for the news as well as for views ${ }^{[3]}$. Accordingly, the purpose of reading English newspaper articles shouldn't be limited to the understanding of the discourse. In the meanwhile, the readers are supposed to make an appropriate evaluation to discourse, namely, doing some critical readings. Despite the fact that all the news media flaunt theirs as an objective and fair media, there is no denying that each news report is more or less influenced by the reporters' and editors' own education and cultural background, political views, personal values, etc. In the production of teaching videos about political news, teachers can choose different mainstream media reports representing several political tendentiousness and for controversial domestic news events, teachers shall select domestic and foreign media reports and lead the students to form their own understandings. 


\section{F. Helping Teachers Manage the Classroom Activity}

In traditional classroom teaching, teachers should pay attention to the movements of the students in the class all the time, because some students talking, sleeping or playing with smart phones may affect other students ' learning. In a flipped classroom, teachers can manage the classroom activities better. Teachers spend more time than ever interacting with the students, rather than demonstrating on the platform. At the same time, the teacher-student or student-student interaction has become more apparent than in the past when the teacher was busy talking to some students. Virtually flipped classroom helps us create a more comfortable and caring learning atmosphere and the students don't regard the learning as a task but a personal need and meaningful thing.

\section{The Design of College English Reading Based on the Theory of the Flipped Classroom}

A flipped class means that the teacher puts what he or she wants to teach before class so that students can watch and learn autonomously, and complete the activities related to knowledge internalization in class.A lot of time is spent in class in helping students solve problems during their self-study before class, and in communicating and discussing between students and teachers or between students and students ${ }^{[5]}$.

When "Flipped Class Model" is applied in College English reading teaching, we can divide the teaching process into three parts: before class, in class and after class. Specifically, the implementation process is as follows:

\section{A. Teaching Design Before Class}

According to our observation and surveys, a large number of students complain that the textbook content is too outdated, too boring and cannot arouse their reading motivation and reading interest, so selecting funny materials to keep pace with the times has become a task for the teacher. The teacher should choose suitable reading materials: the length of materials should not be too long because the flipped class model applied in the reading class is mainly focused on letting students have in-depth reading in class ${ }^{[4]}$. Then, the teacher selects video materials and make one or more films of them according to the teaching contents, advisably each video lasting for ten to fifteen minutes. These videos should corporate such contents as reading purpose and requirements and traditional explanation of language points.

Students are required to complete data reading and watch the videos, understand the contents and requirements of videos and summarize and analyze them. For those contents they can't understand, they can discuss and communicate on the self-learning platform or use other communication tools. They can also resort to the teacher for help.

\section{B. Teaching Design in Class}

Literal level and judging level of teaching design are two levels in reading comprehension. By reading and watching the video before class, many students have understood the content, mostly at the literal level, that is, the readers gradually form the established concept in their mind after thinking by correctly recognizing the function of the English vocabulary and sentence structure and accepting the basic information of the words ${ }^{[5]}$. However, the purpose of reading is to reach the advanced judging level, which contains a number of information collection and feedback activities. To achieve this level, students must carry on deep reading in class. The teacher can ask students to take down notes while reading or write after reading since students have basically solved the language problems by skimming the materials and watching the video before class. Their writing should help students understand the meaning of the discourse and improve their reading skills, for example, to find out the important details and its connection with the topic, know the important plots and relationships between characters, and so on. In the beginning, teachers may organize students to study collectively or have demonstration study mode. After reading a section, the teacher can let students discuss its topic, words and the article's structure, and he or she may also let them associate what they read with his or her own life, or with previously learned contents, or with what have been discussed in class before. All these activities should be completed in the classroom so that students can receive feedback in time.Through the demonstration, students will be abler to 
peruse independently ${ }^{[5]}$. On the basis of the perusal, the teacher can organize students to carry on cooperative study. Students can carry out the group study on their favorite clips. Group study is beneficial for students to get the in-depth analysis of the topics and also helpful to develop the students' ability of empathy and understanding.

\section{Teaching Design After Class}

At the end of the reading lesson, the teacher are advised to have a summary or conclusion of the problems the students confront in the classroom study, give students feedback in time through the network learning platform, and point out the students' weak points in reading and room for improvements. Teachers can also put forward further suggestions to deepen the students' understanding of the texts.

Students are required to consolidate what they have learned in class according to the teacher's comments or suggestions, and reflect on the whole learning process. In this way, English reading abilities as well as critical thinking can greatly be improved.And this is very important not only for professional study but also for the daily life.

\section{Conclusion}

To sum up, teaching college English reading subject in flipped classroom is of extremely profound significance. Flipped classroom is the important booster of the reform of the education informationization in the new period in our country ${ }^{[6]}$. To a certain extent, the flipped class overcomes the disadvantages of the traditional college English reading class, and teachers are supposed to spend more time and energy before class and have better skills in managing the classroom activities. In this mode, students' reading consciousness is greatly upgraded through deep reading in class and the good habits of reading, namely, fast reading before class, reading earnestly in class, and finally carrying on the analysis and forming complicated points of view,will gradually form in the process, so as to practically enhance students’ English reading abilities.

\section{Acknowledgements}

Fund Projects: Scientific Research Project in Colleges and Universities Funded by Education Department of Hunan Province in 2015(No:15C0167) and Scientific Research Project Funded by Changsha Medical University in 2014 (No: KY201457).

\section{References}

[1] Bergmann, J.\&A. Sams. Flipping the Classroom[J].San Bruno: Tech \& Learning,2012.

[2] Berrett, Dan. How "Flipping” the Classroom Can Improve the Traditional Lecture[J]. The Education Digest, 2012.

[3] Cunjie Li, A Probe into English Reading Teaching Mode Based on the Theory of Flipped Class[J]. Journal of Kaifang Institute of Education, 2016(1):93-95.

[4] Haiyi Wu\& Mei Yang, The Application of "Flipped Classroom”Mode in College English Reading Teaching[J]. Journal of Lishui University,2016(1): 115-119.

[5]Bretzmann Jason. Practical Strategies for Flipping Your Class[M].New Berlin: the Bretzmann Group, LLC, 2013: 56-81.

[6] Haiyan Lu.Feasibility Analysis on the Application of Micro-class Based "Flipped Classroom”Mode in College English Teaching[J].Computer-assisted Foreign Language Education, 2014(4):33-36. 